\title{
Halal Remix in Rap Deen Squad Music Genre: Expression of Islamic Identity of Millennial Muslims
}

\author{
S H Arnus ${ }^{1}$, Mansur ${ }^{2}$, A P Utomo ${ }^{3}$, Fadlullah ${ }^{4}$ \\ Institut Agama Islam Negeri Kendari, Perum Baruga Nusantara C/25 Kendari ${ }^{1}$ \\ Institut Agama Islam Negeri Kendari, Griya Wahana Permai B/5 Kendari ${ }^{2}$ \\ Institut Agama Islam Negeri Kendari, jl.Martina Marta Tiahahu Baruga Kendari ${ }^{3}$ \\ Institut Agama Islam Negeri Kendari, Sinjai Sulawesi Selatan ${ }^{4}$ \\ \{hadijaharnus@iainkendari.ac.id'1 , mansurrahman7291@yahoo.com², bagus.sumbor@gmail.com³, fadel@gmail.com ${ }^{4}$ ?
}

\begin{abstract}
This study departs from the author's observation of the music tastes of listeners of Radio Fajar IAIN Kendari who like the Rap music genre, especially Deen Squad's song, which calls its music a Halal Remix. This can be seen from the large number of reservations for Deen Squad songs in every the program of Radio Fajar Radio. It is interesting for writers to examine what they want to be expressed through the Rap music genre regarding their identity as Muslims. In addition, the writer also wants to find out what da'wah messages are contained in the Deen Squad's rap music genre song. This type of research is descriptive qualitative by using interview and observation techniques as well as content analysis. The results showed that the informants liked the halal remixes of the Deen Squad rap music genre because the rhythm was so dynamic and driving enthusiasm. The lyrics of the song Deen Squad can also explain to the world the stereotypes about Islam that they cannot express so far as young Muslims. This study found that Deen Squad songs are carrying messages of peace, telling the world that Islam is not a terrorist religion and that every streotype about Islam has a meaning.
\end{abstract}

Keywords: Deen Squad, Rap, Halal Remix, Millennial Muslim

\section{Introduction}

If you are an early 80 s generation then in your teens you certainly know Iwa $\mathrm{K}$, who is popular with his rap music genre in the mid 80s to 90 s. Iwa $\mathrm{K}$ appeared with a new color in the midst of pop music which became a trend in Indonesian society at that time. Rap Iwa K became a new idol for young people at that time, which was synonymous with freedom of expression, creativity, and very critical of a rule. After the generation of Iwa K, there were not many singers with similar genres that emerged in Indonesia that were as popular as Iwa $\mathrm{K}$. The genre of rap music began to be abandoned by the Indonesian people as other musical genres emerged that were increasingly diverse [1].

The development of the internet and information and communication technology gave birth to many social media including YouTube. This media site offers a variety of videos, including music video clips. The development of YouTube brought changes in the field of marketing in national music even the world. Many record companies are out of business. Buyers of tapes are almost non-existent, because all songs can be downloaded for free through internet media including YouTube. The development of this media also makes people free to choose the genre of music that they enjoy. Only with an account on YouTube, they can publish their creative work. This makes the emergence a variety of new music genres created by netizens.

The development of the internet and social media, especially YouTube, eventually became a music reference for entertainment broadcasts on television, radio and other mainstream media. The variety types of music also affects the variety of listeners' musical tastes, especially in radio. This happened IAIN Kendari's Fajar FM community radio, which is a community radio within the scope of the Kendari IAIN. Most of the radio broadcasts are da'wah. This radio is a community radio, that is a broadcasting laboratory for Islamic Communication and Broadcasting Study Program (KPI) students. Based on preliminary observations, it was found that as a community radio that carries the contents of Da'wah in its broadcasts, Radio Fajar fills its broadcast content with Islamic or religious songs and music. The music displayed is not only gambus music, Qasidah or marawis which is commonly known as the Islamic music genre, but also shows the genre of Islamic pop and rap music. Based on data from the recapitulation of song reservations on the radio by listeners on all shows on Radio Fajar, it can be seen that the number of requests to play rap music especially songs from Deen Squad is quite high.

Based on the explanation above, it is interesting for the writers to examine about the reasons why community members like the rap music genre which incidentally is not easy listening compared to music genres 
that are more familiar in the community, such as the Gambus Sabyan music genre that is currently popular. The writer also wants to know what expressions they want to show by listening to or liking the song.

\section{Method}

This type of research is descriptive qualitative. To find out what expression to convey by enjoying Deen Squad's halal remix, researchers used to interview and observation techniques. The informants in this study were members of the Fajar FM Radio community based on data obtained often ordering Deen Squad songs through several programs on Fajar FM Radio. Researchers interviewed 20 informants who were members of the community or listeners of the IAIN Kendari Fajar radio. To find out what messages to be conveyed by Deen Squad in the lyrics of the song, the writer uses content analysis techniques, to the poems of three Deen Squad songs namely Muslim Man, Spread Out, and Ooouuu !!!.

\section{Results and Discussion}

IAIN Kendari Fajar Radio which is a community radio, has 90 percent listener segmentation aged 17-25 years, which is currently trend with term millennial. The program that aired on this radio $60 \%$ contained religious content or dakwah, the rest was around the IAIN Kendari campus and general information about Kendari City.

The rapid development of the internet has changed the direction of music production, especially in Indonesia, which was previously produced in recording studios by music producer companies, now various music can be downloaded via internet, one of them is via YouTube. Youtube is social media whose content is video, providing devices or facilities for making channels or channels. This channel is owned by people who already have an account. Through this channel users can upload videos based on the category they want [2].

The rapid development of YouTube's media has affected the operation of mass media, especially radio. Based on observations and interviews with broadcasters and crew from Radio Fajar FM stated that, most of the songs that aired on the Radio Fajar program were songs downloaded on Youtube. Usually listeners order songs based on what is being viral on social media, so there is a very close relationship between music or videos on YouTube with listeners' tastes. The advantage of radio media is that listeners can send messages to fellow fans or fellow members of the radio community. Most of them are Kendari IAIN students with different faculties and or different study programs. Even though in the millennial era like the current mainstream media began to be abandoned by the rise of social media, but the radio in this community is still quite popular.

The millennial music tastes trend, especially the Fajar RadioIAIN Kendari community, which is currently oriented to YouTube, makes the choice of listeners' musical tastes very diverse, including religious music tastes. In the genre of religious or Islamic music is currently trending gambus music performed by Sabyan Gambus with the vocalist Nisa Sabyan, which is currently popular. Gambus music performed by the music group is packaged in a more attractive form with the target for young people. This is a phenomenon in the world of religious music. During this time gambus music is music that is less favored by young people, the stigma of gambus music is synonymous with middle eastern music and does not have innovation and seem old-fashioned. Sabyan Gambus music genre has finally become one of the favorite listeners of Radio Fajar which is a community that is mostly young people.

In addition to Sabyan Gambus music, the rap music genre is also a favorite of the Fajar Radio community, especially rap performed by Deen Squad. The rap duo song is known as halal remix, where the rap song that is delivered by the poem contains Islamic poetry or contains da'wah values. Deen Squad is a rap duo consisting of Jae Deen and Karter Zaher. They are two friends who met in 2015 for studying at the same place, Corleton University Ottawa. Karter Zaher A man of middle eastern descent who was born in Ottawa, Ontario on February 17, 1992. While Jae Deen, a man of Ghanaian-Canadian descent who was born on September 23, 1994. They also formed a rap duo named "Deen Squad". They upload their videos to Youtube and get lots of viewers, they attract attention on CNN, BBC and CBC national news, and they are talked about in a variety of media [3].

Rap music is a genre of music created in the United States in the 1970s involving rap technique, which is a way of speaking that is voiced through rhythmic rhymes, accompanied by rhythmic background music. There is also another opinion that says "rap" is another name for bebop. This technique then developed as part of rap, a branch of culture that has 4 key elements namely Mcing / rapping, Djing / scratching, breakdancing, and graffiti writting. Sampling and beatboxing are also included as part of rap music. Rap music grew starting from The Bronx in New York City and then continued to grow rapidly throughout the world. Rap music was first introduced by an Afro-American, Grandmaster Flash and The Furious Five [4].

\subsection{RAP Daan Squad's Music as an Expression of Millennial Muslim Islamic Identity}


Rap music is not easy listening but is liked by members of RadioFajarIAIN Kendari community becomes interesting for writers to examine more closely related to it. When asked to the broadcasters and crew of Radio Fajar IAIN Kendari, the reason for showing Deen Squad's halal remix was originally because it wanted to create variations of music that aired for listeners. Because Radio Fajar's listeners are millennial Muslims, Deen Squad's halal remix music is a choice. According to the rap music informants is also a new alternative in Islamic music, so that religious music that is displayed is not always synonymous with gambus music, qasidah, and music that smells of the Middle East [5]. By showing rap music gives a new color to the listener so it is not boring. The rap music playback on several programs aired by Fajar Radio received positive responses from listeners, many of whom asked to be played back on other Fajar Radio programs.

When the authors conducted interviews with informants, it was found that listeners liked the Deen Squad's halal remix because their song was "anti-mainstream" unlike the currently popular song sung by almost everyone, they assumed that their musical tastes were not common and tended to not overly follow music that was a trend in society at that time. Rap music is also according to the informants is a dynamic music that inspires enthusiasm, in accordance with the soul of a dynamic and creative young people. In addition it was explained that they like the speech style of rap music that is fast, called similar to someone who is angry or nagging. According to interviews with informants, the speaking style of people who are complaining is a special attraction for them to rap music, when singing rap songs Deen Squad, as if they are freeing the burden of their feelings and thoughts.

Other informants expressed their interest in Deen Squad because this music group is unique, because it carries rap songs but the lyrics contain Islamic messages or contain dakwah content. The informants also explained that some of the lyrics of the song Deen Squad contained protests against the many assumptions of people about Islam which is identical with terrorists. From the song can represent their displeasure expressions of wrong assumptions about Islam, the assumption that states that Islam is a terrorist religion because in the teachings of Islam no one teaches about the actions that justify to kill fellow human beings whoever these humans are.

In another song of Deen Squad, "Muslim Man" reveals the identity of clothing or appearance of a Muslim such as wearing a turban, robe, trousers, and maintaining a beard. Such identity is assumed to be identical with groups affiliated with terrorists. The song represents an expression of their displeasure with the assumption, because it is an identity that is inherent in them. According to the informants that the interesting thing from the rap song Deen Squad which contains clarification about the wrong world view about Islam, is very straightforward and it cannot be done by other types of music, because the character of rap music is firm and straightforward.

They added that they considered the rap song to be an expression of their displeasure with the wrong assumptions about Islam so far. Deen Squad song is a medium to show someone's expression. According to the informant, songs and music will be different from verbal expressions directly, such as in the form of speeches, writings, attitude statements or even demonstrations. Songs and music can convey meaning in a subtle but broad scope. And why is a song considered as a medium to express one's expression, because the song is not addressed to individuals so that anyone can sing it and enjoy it. According to them the song is a better way to offend a people or group. Songs are considered more subtle in expressing displeasure. With the song that was delivered by Deen Squad can represent their protest of negative assumptions about Islam, the stereotype for the appearance of Muslims like those who have been synonymous with terrorist labels when using beards, wearing turbans, wearing veils, robe and trousers. At least this song from Deen Squad as the media of choice for millennial Muslims ofRadioFajarIAIN Kendari community compared to expressing their protest through speeches, writings or even through demonstrations.

\subsection{Results of content analysis of the song deen squad}

In this study the authors analyzed three songs belonging to Deen Squad namely Muslim Man, Spread Out, and OOOUUU !!!. . These three songs were chosen because they were the most wanted by listeners in RadioFajar IAIN Kendari community.

The song Muslim Man is one of the songs by the rap genre Deen Squad created by Kart Zaher and Jae Deen. In this song they attack Islamophobia. This song confirms that Muslims are not terrorists. Muslim Man song itself is inspired by the tragedy of suicide bombings and the tragedy of the Paris bombing which is always associated with Islam. So that makes the song "Muslim Man" become viral on social media. Deen Squad in this song also wants to emphasize that the beard is not a symbol of terrorism but by extending the beard is the Sunnah of the apostles, in this lyrics Deen Squad emphasizes more on the sense of "No, I am not a terrorist" even this sentence is repeated delivered, this is the point important in this case because Islamophobia that occurs in Europe which forms a paradigm of thinking about society about terrorist Islam. They hope their music will inspire Muslim youth to be proud of their religion and become more observant in carrying it out, they also want to show the other side of Islam to non-Muslims. "We want to end Islamophobia, our message is not only for 
Muslims, this is a message for all, to fit people throughout the world" (http // WWW.DeenSquad against Islamophobia. With music).

The spread out song is one of Deen Squad's songs, the cover of the twenty one pilits song under the title stressed out, which was released on May 28, 2016. In this spread out song Deen Squad expressed his desire to unite Islam. The spread out song itself was inspired by the divisions that occurred in Islam itself so that gave birth to many sects, such as Shi'a, Sunni, Salafi and others. Deen Squad wants Islam to become one like the Age of the Prophet, where Islam is only one without a sect. The message of preaching contained in this stanza is how then Deen Squad hopes to never have a certain way of worship, because by having a certain way of worship describing a particular sect and this is what Deen Aquad does not want, because it impacts on the problem of the divisions of the Islamic Ummah. In this song Deen Squad calls for Muslims to be preoccupied with calling for messages of peace, messages of kindness to non-Muslims, but what becomes a big problem is the division between fellow Muslims themselves. therefore we must unite for the glory of Islam as a monotheistic, one religion.

OOOUUU !!! Is one song by Deen Squad which was released on October 29, 2016. Not much different from the song Spread Out, in the song OOOUUU !!! Deen Squaad put more emphasis on the unity of the Islamic ummah itself, supporting each other as much as the Islamic ummah and not judging each other. Deen Squad also explained in this song that they preach with rap music has absolutely nothing to do with nonMuslims because they are true Muslims. In this song also sends a message that apart from the controversy about music is haram. That with rap music media presented by Deen Squad is a halal entertainment for consumption by Muslims, this is a new thing that is used as a media for da'wah.

One of the characteristics of young people who are currently called Millennial trend always want to highlight their identity, of course they want to look different than people in society in general, they always want to express what they think and feel through music. Djohan [6] expressed self-expression in music is the emotion produced in a music. Emotions in the field of musicology are interpreted as slow (tempo elements) a musical composition. Emotions brought by some music can make a person change and have a different mood. Wrong assumptions about Islam, wrong assumptions about the appearance of Islamic identity can be expressed through rap music, one of them is by making the song a favorid and a way to express their thoughts and feelings as a Muslim.

Why rap music has become a genre of music with a fast and decisive tempo. The rap music originally contained protests against government regulations that were curbing, social criticisms, Rap music mostly tells about life around black people and shouts as well as their conscience protests to the government which is not fair. Rap music lyrics tend to be hard and decisive. [7]. The rap song character is indeed owned by young people who have critical, creative character, and are free to express their thoughts and feelings. Through this rap music they can express their identity as a Muslim that Muslims are not terrorists, Islamic teachings never teach to kill fellow human beings, all Muslim appearance with a turban, robe, veil, pants and beard do not become streotype that he is a terrorist.

\section{Conclusion}

The rise of negative assumptions about Islam identified with terrorism received criticism from some members of Radio Fajar IAIN Kendari community. They express their displeasure through rap music Deen Squad assumptions about their Muslim identity such as using a turban, robe, veil, trousers and so on. They regard music as a bridge to explain the wrong assumption to the world. Protests or expressions of displeasure are expressed through rap music that is firm and straightforward in poetry and rhythm. Moreover, the da'wah messages contained in the lyrics of Deen Squadsongs can explain the various negative assumptions of the world about Islam.

The messages contained in the three poems sung by Deen Squad entitled Muslim Man, Spread Out and OOOuuhh !! are a message of peace, that Islam is a religion that loves peace. This message is mainly addressed to Islamists who think that Islam is synonymous with terrorism and try to erase their stereotypical assumptions of Islamic dress attributes that are sometimes interpreted negatively by non-Muslims. In these songs, Deen Squad also calls for unity among all Muslims themselves regardless of the sects they belong to.

\section{Reference}

[1] B. Barendregt and W. Van Zanten, "Popular music in Indonesia since 1998, in particular fusion, Indie and Islamic music on video compact discs and the internet," Yearb. Tradit. Music, pp. 67-113, 2002. 
Bandung: Remaja Rosdakarya, 2017.

[3] "Muslim Rap.".

[4] A. Masyyita, "Strategi Dakwah Islam Akun Youtube Ibnu The Jenggot Dalam Meningkatkan Kesadaran Nilai-Nilai Islam.".

[5] J. Otterbeck, "Battling over the public sphere: Islamic reactions to the music of today," Contemp. Islam, vol. 2, no. 3, pp. 211-228, 2008.

[6] Djohan, Psikologi Musik. Yogyakarta: Best Publisher, 2009.

[7] M. Lubis, Musik Hip-Hop dan Identitas Diri Komunitas Dwell dan Exito (Studi Kualitatif Mengenai Musik Hip-Hop dan Identitas Diripada Komunitas Dwell dan Exito). 2018. 